\title{
Gene profiling of B lymphoblastoid cell lines from DRESS patients after drugs incubation
}

\author{
Sébastien Calbo ${ }^{*}$, Xavier Camous ${ }^{2}$, Baptiste Janela², Kim Périchon", Jinmiao Chen², Edmond Chua ${ }^{2}$, \\ Josephine Lum ${ }^{2}$, Francesca Zolezzi ${ }^{2}$, Michael Poidinger ${ }^{2}$, Philippe Musette ${ }^{1}$ \\ From 6th Drug Hypersensitivity Meeting (DHM 6) \\ Bern, Switzerland. 9-12 April 2014
}

\section{Background}

Drug reaction with eosinophilia and systemic symptom (DRESS) is a severe drug-induced cutaneous reaction with visceral involvement and blood abnormalities associated with reactivations of herpes-virus family i.e., EBV, HHV-6, HHV-7 and CMV. Recently, we demonstrated that the immune response in DRESS, previously thought to be directed only against drug components, is also mediated by herpes-virus specific cytotoxic CD $8+\mathrm{T}$ lymphocytes which home to the skin and visceral organs.

\section{Method}

An in vitro model based on EBV-transformed B lymphoblastoid cells lines from DRESS patients and healthy donors were used to study the specific effect of drugs on gene expression. Gene expression profiles were obtained for cell lines treated or not by allopurinol, amoxicilline, sulfamethoxazole, valproic acid or carbamazepine.

\section{Results}

Significant differential gene expressions were found in DRESS patients' cell lines in comparison with healthy donors' cell lines after sulfamethoxazole or valproic acid treatment. Ingenuity pathways analysis revealed that differentially gene expressed following sulfamethoxazole treatment were playing a role in antigen presentation, immune cell trafficking, proliferation and inflammatory response. We confirmed modified gene level expression at the protein level by flow cytometry. Finally, we performed a functional assay to address the role of sulfamethoxazole on immune response by setting up an in vitro proliferation assay.

${ }^{1}$ Inserm U905, Normandie Univ, France

Full list of author information is available at the end of the article

\section{Conclusion}

Our results suggest a new role for drugs in the pathogenesis of DRESS that could enhanced the immune response in vivo.

\section{Authors' details}

'Inserm U905, Normandie Univ, France. ${ }^{2}$ Singapore Immunology Network, A STAR, Singapore.

Published: 18 July 2014

doi:10.1186/2045-7022-4-S3-P123

Cite this article as: Calbo et al:: Gene profiling of B lymphoblastoid cell lines from DRESS patients after drugs incubation. Clinical and Translational Allergy 2014 4(Suppl 3):P123.
Submit your next manuscript to BioMed Central and take full advantage of:

- Convenient online submission

- Thorough peer review

- No space constraints or color figure charges

- Immediate publication on acceptance

- Inclusion in PubMed, CAS, Scopus and Google Scholar

- Research which is freely available for redistribution
() Biomed Central

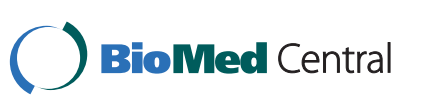

